\title{
Seasonal Pattern in the Vertical Distribution of Dinoflagella in the Southern Caspian Sea
}

\author{
Tahami FS \\ Assistant professor, Member of faculty of the Caspian Sea ecology research institute, Iran \\ *Corresponding author: Tahami FS, Assistant professor, Member of faculty of the Caspian Sea ecology \\ research institute, Iran; E-mail: farnaztahamy@gmail.com
}

Received Date: 28 July, 2018; Accepted Date: 21 December, 2018; Published Date: 01 February, 2019

\begin{abstract}
This study was conducted in the spring, summer, autumn and winter, at 40 study sites from 8 transect between Astara to the border of Hasangholipour of the Southern Caspian Sea in Iran. A total of 24 species were identified from the phylum Dinoflagella. The maximum density Dinoflagella $28.17 \pm 27.14$ (n.m ${ }^{3} \times$ $10^{6}$ ) and maximum biomass $3349 \pm 336 \mathrm{mg} \cdot \mathrm{m}^{-3}$ respectively. Most species diversity Dinoflagellates in winter (17 species) has been that species Exuviaella cordata ، Goniaulax polyedra ' Peridinium achromaticum ، Peridinium latum ، Prorocentrum praximum Prorocentrum scutllum were observed in all seasons. Dinoflagella with an average density of $28.17 \pm 27.14\left({\mathrm{n} . \mathrm{m}^{-3} \times}^{-1}\right.$ $\left.10^{6}\right)$ and the average biomass annually $349 \pm 336\left(\mathrm{mg} \cdot \mathrm{m}^{-3}\right)$ of approximately $9 \%$ density and $4 \%$ biomass phytoplankton of area in the country. The diversity, density and biomass of Dinoflagella have significant changes. Ongoing changes in microscopic plants including Dinoflagella can have effect on fish migration patterns, their growth rate, mortality rate, and of course the critical gas concentrations in the atmosphere.
\end{abstract}

\section{Keywords}

Phytoplankton; River; Shannon-Weaver; Species; terrestrial plants.

\section{Introduction}

In recent years, considerable changes in terms of the phytoplankton species, diversity and even blooming in the Caspian Sea waters were observed. Caspian Sea having valuable resources of flora and fauna, the diversity of commercial fishes, especially reserves the exclusive sturgeon, along with wetlands and deltas and the Gulf leading to it, as well as reserves abiotic such as oil and gas resources and transportation Central Asia is a region that is very important to investigate the ecological conditions of the Caspian Sea [1] Despite the small size of plankton, their role in the production on the Earth is impressive and almost identical to series production of the world's terrestrial plants. In the Caspian Sea various factors affect the ecosystem that one of the most important is season [2].

The phytoplankton of the southern Caspian Sea during the years 1991-2010 by the Caspian Sea Ecological Research Center was conducted in various projects. The branch Dinoflagella was one of the important branches of abundance, biomass and diversity and has been in different seasons with different values. Dinoflagella are known because of their whip-like frills. Some of them live by photosynthesis, and some other types of plankton eat others [3] and some are able to produce light. Some of the plankton and fish parasites and others are able to secrete a toxic substance [4].

These toxins can be a lot of aquatic animals poisoned through eating or being eaten to move along the food chain. Some Dinoflagella in an increase may not release toxic substances. This is a familiar phenomenon known as red tides, which in some cases are killing millions of fish and changes resulting from feeding zooplankton and phytoplankton invasion of Mnemiopsis population which is strongly influenced by sea waves and seasonal changes [5]. Roohi [6] expressed a high level of primary production probably due to the entry of nutrients from rivers Sefidrood and Babolsar and Anzali that zooplankton is important factor in reducing transparency and increasing the density of phytoplankton in shallow areas offshore and in Results due to the presence of large rivers like the Anzali, increased phytoplankton in the West of the Caspian Sea [7]. According to Špoljar Research in 2018 $[8,9]$, abiotic factors and food resources, as well as zooplankton assemblage not show significant difference along the gradient of habitat complexity but exhibited pronounced variability among these water bodies. The Shiganova [10] stated that the Black Sea by the Danube River nutrient overload causes plankton blooms or were eutrification. In this study, we tried to Dinoflagella population of the species, density and biomass must be examined. 


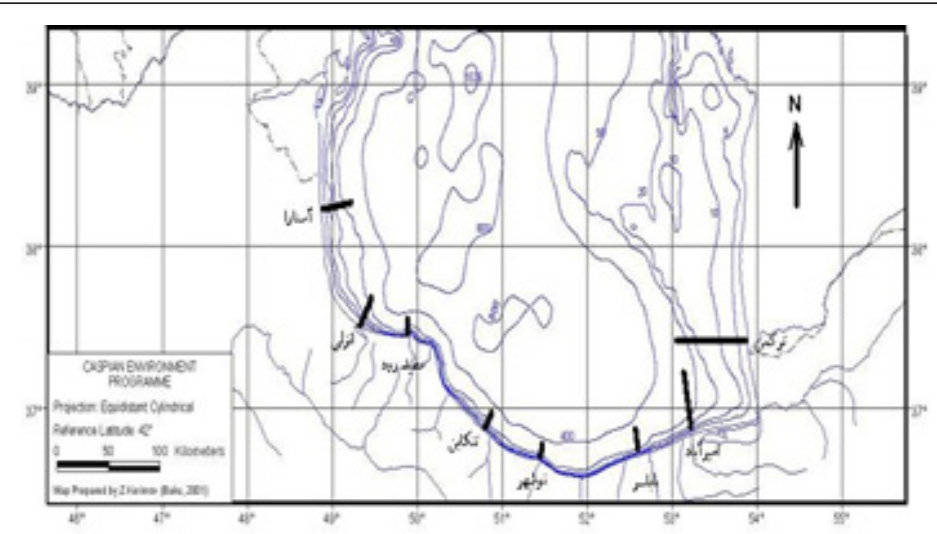

Figure 1: Microscopic algae sampling stations in the southern basin of Caspian Sea, 2010.

\section{Methods}

This study was conducted in the southern Caspian Sea basin, which the sampling at different stations and depths were performed for one year and by the Gilan research vessel in spring, summer, autumn and winter, 2010, and with Rottner sampler (maximum volume of 2 liters) [11]. Sampling areas were selected at the 8 transects: Astara, Bandar Anzali, Sefidrood entrance, Tonekabon, Noshahr, Babolsar, Amir Abad port, Bandar Turkman (Figure 1). In each transect, 5 stations at the depths of $5 \mathrm{~m}$, $10 \mathrm{~m}, 20 \mathrm{~m}, 50 \mathrm{~m}$ and $100 \mathrm{~m}$ were considered and the sampling was conducted by a research ship, Guilan. Laboratory analyses were performed according to the APHA method $[1,12]$. In this method, the samples are updated in the darkness to be completely precipitated. Then, drained it with a special siphon, and the remaining sample was centrifuged at a speed of 3,000 rpm for several minutes to reach a volume of $20-25 \mathrm{ml}$.

In the laboratory, the samples were investigated and counted in two qualitative steps and one quantitative step by the slabs and lamellas of $24 \times 24 \mathrm{~mm}$, and a microscope with magnification of $10 \times, 20 \times$, and $40 \times$. Calculations of mean and standard deviations and preparation of their figures were performed by Excel 2007 software. Frequency data and the algae biomass showed a normal distribution. Comparisons of the mean data were performed by multiple analysis of variance (ANOVA) and Duncan test. In variance analysis, the density and biomass of different branches were considered as dependent variables and the seasons, transects and depths were independent variables.

The species diversity index was calculated according to the Shannon-Weaver formula [10] and by the following

$$
H^{1}=-\sum p_{i} \ln p_{i}
$$

$\mathrm{H}^{\prime}$ is the Shannon-Weaver index (nits per individual) and is the relative abundance of species.

\section{Results}

In this study, a total of 24 species of Dinoflagella were identified, and in winter were observed most species and the lowest were in spring (Table 1 \& Figure 2).

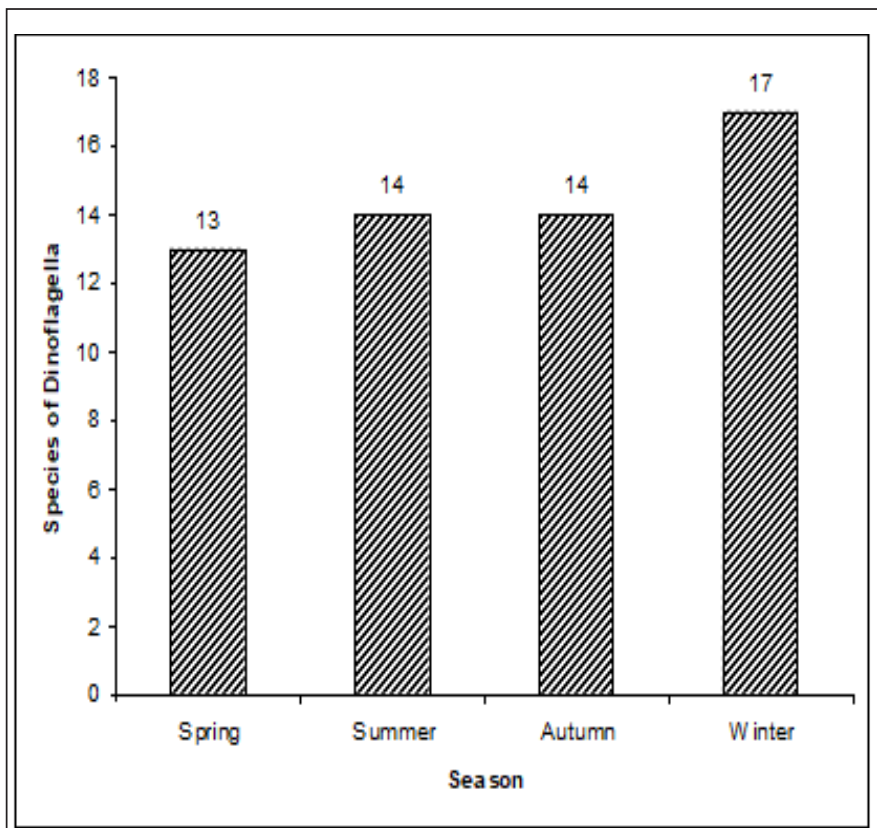

Figure 2: Totally species of Dinoflagella in different seasons in the south Caspian Sea water environment.

The species Exuviaella cordata, Goniaulax polyedra, Peridinium achromaticum, Peridinium latum, Prorocentrum praximum and Prorocentrum scutllum in all seasons were observed and species Glenodinium caspicum, Glenudinium danicum, Goniaulax monacantha, Goniaulax sp, Goniaulax spinifera, Peridinium cinctum, Peridinium subsalsum, Peridinium thricoidum and Prorocentrum micans were observed in only one season (table 1).

Table 2 - Density/Abundance of Dinoflagella species observed in different stations, depths and seasons

Most of the Dinoflagella species were observed in the spring and then increased because of sunlight in the depth of 20 meters and 10 meters deep in autumn, the maximum Dinoflagella in this deep. But the maximum Dinoflagella in the winter were 


\begin{tabular}{|c|c|c|c|c|}
\hline species & Spring & Summer & Autumn & Spring \\
\hline Exuviaella cordata & + & + & + & + \\
\hline Exuviaella marina & + & + & - & + \\
\hline Glenodinium behningii & + & - & + & + \\
\hline Glenodinium caspicum & - & - & - & + \\
\hline Glenudinium danicum & - & + & - & - \\
\hline Glenodinium lenticula & + & - & + & + \\
\hline Glenodinium penardii & + & + & + & - \\
\hline Goniaulax monacantha & - & + & - & - \\
\hline Goniaulax sp & - & - & - & + \\
\hline Goniaulax digitale & + & + & - & + \\
\hline Goniaulax polyedra & + & + & + & + \\
\hline Goniaulax spinifera & + & - & - & - \\
\hline Gymnodinium SP & - & + & + & + \\
\hline Gymnodinium variabile & + & + & - & + \\
\hline Peridinium achromaticum & + & + & + & + \\
\hline Peridinium latum & + & + & + & + \\
\hline Peridinium cinctum & - & - & + & - \\
\hline Peridinium subsalsum & - & - & - & + \\
\hline Peridinium sp & - & - & + & + \\
\hline Peridinium thricoidum & - & - & + & - \\
\hline Prorocentrum micans & - & + & - & - \\
\hline Prorocentrum obtusum & - & - & + & + \\
\hline Prorocentrum praximum & + & + & + & + \\
\hline Prorocentrum scutllum & + & + & + & + \\
\hline
\end{tabular}

Table 1: Observed Dinoflagella in different seasons in the south Caspian Sea water environment.

in the surface. In most stations in surface and 10 meters depth, the highest number of species were observed and gradually decreased with increasing depth so that the number of species of Dinoflagella in all seasons in 100 meters depth had the lowest number of species (Table 2).

In the spring, the number of Dinoflagella species in different transects are respectively Babolsar, Amirabad, Noshahr, Tonekabon, Turkmen, Astara, Anzali and Sefid Rood. In summer, the number of Dinoflagella species in different transects are Anzali, Tonekabon, Noshahr, Babolsar, Sefid Rood, Astara, Turkmen and Amirabad, respectively (Table 2).

In the Autumn Anzali Transect had the most species of Dinoflagella and then followed by Sefidrud, Astara Tonekabon, Noshahr, Amirabad and Babolsar and in summer. In the transect of Turkmen, the number of branches of the Dinoflagella branch was less than the other half-lines, and in the Anzali area, a maximum of
8 species of the Dinoflagella branch was observed at a depth of $20 \mathrm{~m}$. In the mid-line of the white river, at Dinoflagella depths of 20 meters, six species were reached, and with increasing Depth, number of species decreased (Table 2).

In the autumn, the number of species of Dinoflagella, half lines are respectively Bubsler, Sefidrud, Tonekabon and Turkmen, Anzali and Amirabad, Noshahr and Astara. In this chapter, the highest species were observed at the depth of 10 meters and the number of 12 species were observed in the semi-circle of halflength. The trend of variation of Dinoflagella species in the halflines of the winter season include Tonekabon, Babolsar, Noshahr, Sefidrood, Amirrabad, Anzali and Astara (Table 2).

As in Figure 2, Shannon index $(\mathrm{H})$ in the spring and gradually in summer, autumn and winter decreased index, Shannon Region West spring (0.96) and Shannon lowest in the East of autumn (0.47), respectively. 


\begin{tabular}{|c|c|c|c|c|c|c|}
\hline Stations & Seasons & Surface & 10 Meters & 20 Meters & 50 Meters & 100 Meters \\
\hline \multirow{4}{*}{ Astara } & Spring & 8 & 5 & 7 & 3 & 3 \\
\hline & Summer & 2 & 6 & 4 & 1 & 1 \\
\hline & Autumn & 7 & 6 & 3 & 1 & 1 \\
\hline & Winter & & 5 & 3 & 2 & 1 \\
\hline \multirow{4}{*}{ Anzali } & Spring & 8 & 8 & 5 & 5 & 3 \\
\hline & Summer & 6 & 6 & 8 & 1 & 1 \\
\hline & Autumn & 10 & 10 & 2 & 3 & 0 \\
\hline & Winter & 6 & 6 & 2 & 3 & 3 \\
\hline \multirow{4}{*}{ Sefidrood } & Spring & 11 & 9 & 8 & 3 & 2 \\
\hline & Summer & 4 & 4 & 6 & 1 & 0 \\
\hline & Autumn & 9 & 12 & 5 & 2 & 2 \\
\hline & Winter & 9 & 6 & 5 & 1 & 2 \\
\hline \multirow{4}{*}{ Tonekabon } & Spring & 8 & 11 & 7 & 3 & 3 \\
\hline & Summer & 6 & 6 & 5 & 2 & 1 \\
\hline & Autumn & 8 & 9 & 8 & 3 & 2 \\
\hline & Winter & 14 & 7 & 4 & 4 & 0 \\
\hline \multirow{4}{*}{ Noshahr } & Spring & 9 & 9 & 7 & 6 & 4 \\
\hline & Summer & 7 & 8 & 3 & 2 & 0 \\
\hline & Autumn & 6 & 8 & 4 & 3 & 1 \\
\hline & Winter & 10 & 7 & 5 & 0 & 2 \\
\hline \multirow{4}{*}{ Babolsar } & Spring & 10 & 12 & 0 & 7 & 3 \\
\hline & Summer & 5 & 0 & 9 & 1 & 2 \\
\hline & Autumn & 12 & 9 & 7 & 7 & 0 \\
\hline & Winter & 9 & 10 & 8 & 0 & 0 \\
\hline \multirow{4}{*}{ Amirabad } & Spring & 12 & 12 & 8 & 3 & 3 \\
\hline & Summer & 2 & 3 & 3 & 1 & 1 \\
\hline & Autumn & 4 & 9 & 9 & & 3 \\
\hline & Winter & 5 & 8 & 7 & 2 & 0 \\
\hline \multirow{4}{*}{ Torkman } & Spring & 8 & 9 & 11 & 3 & 2 \\
\hline & Summer & 2 & 3 & 3 & 2 & 2 \\
\hline & Autumn & 5 & 10 & 10 & 4 & 1 \\
\hline & Winter & & & & & \\
\hline \multirow{4}{*}{ Total Species } & Spring & 74 & 75 & 53 & 33 & 23 \\
\hline & Summer & 34 & 36 & 41 & 11 & 8 \\
\hline & Autumn & 61 & 73 & 48 & 23 & 10 \\
\hline & Winter & 53 & 49 & 34 & 12 & 8 \\
\hline
\end{tabular}

Table 2: Number of Dinoflagella species observed in different stations, depths and seasons. 

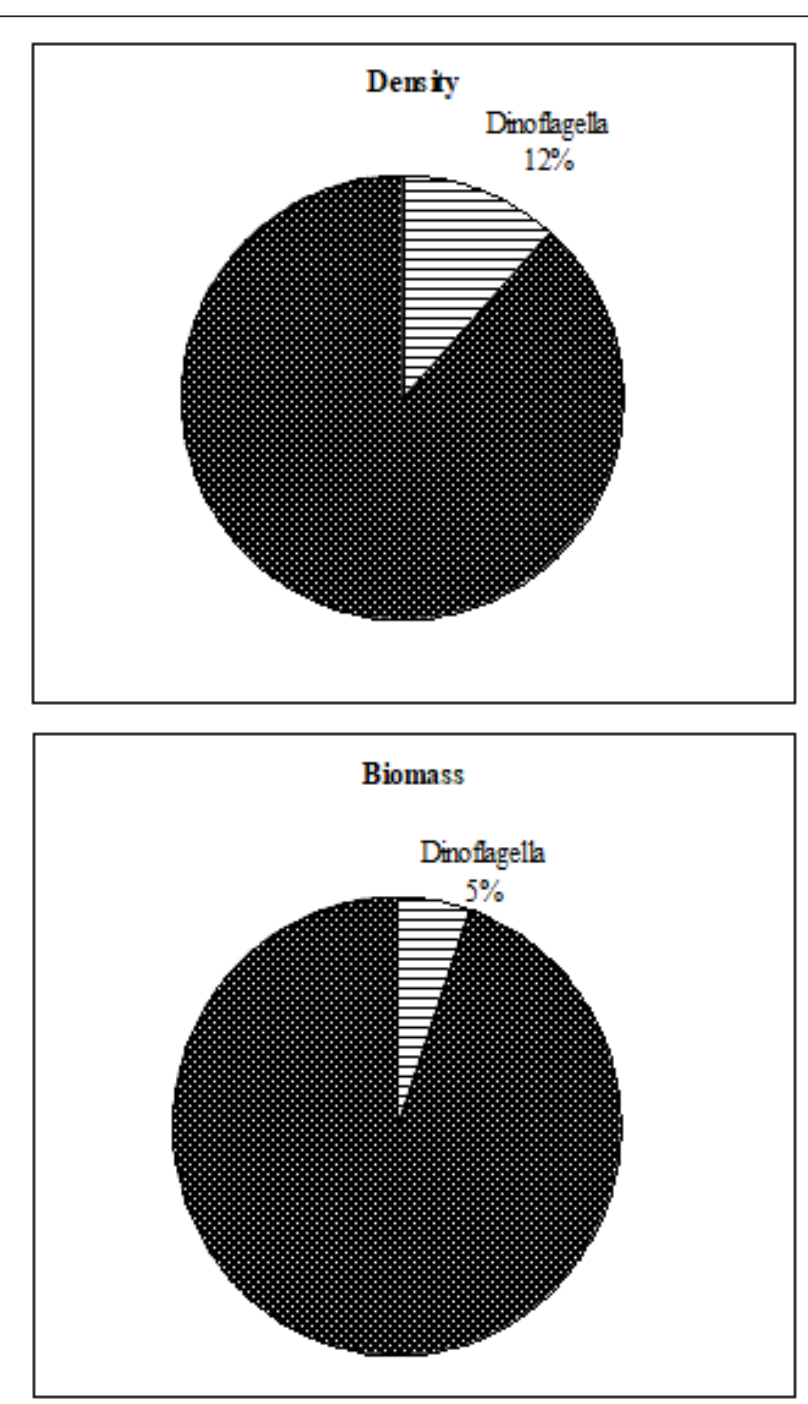

Figure 3: Percentage of density and biomass of Dinoflagella in total of year.

\begin{tabular}{|l|l|l|}
\hline Phytoplankton & $\begin{array}{l}\text { Density } \\
\left(\mathrm{n} \cdot \mathrm{m}^{-3} \times 10^{6}\right)\end{array}$ & $\begin{array}{l}\text { Biomass } \\
\left(\mathrm{mg}^{-3} \mathrm{~m}^{-3}\right)\end{array}$ \\
\hline $\begin{array}{l}\text { Dinoflagella } \\
\begin{array}{l}\text { Total Phyto- } \\
\text { plankton }\end{array}\end{array}$ & $28.17 \pm 27.14$ & $349 \pm 336$ \\
\hline
\end{tabular}

Table 3: The highest density (number per cubic meter $\times 106$ ) and biomass (milligrams per cubic meter) of Dinoflagella.

In the annual study, the average density of phytoplankton was $348.38 \pm 81.21$ (number $/ \mathrm{m}^{3} \times 10^{6}$ ), Dinoflagella branch with a average density of $28.27 \pm 27.47$ (cubic meters $\times 10^{6}$ ), about $12 \%$ of total plankton density was formed. Also, in this study, the average of phytoplankton biomass was $6564 \pm 686\left(\mathrm{mg} / \mathrm{m}^{3}\right)$, which The Dinoflagella branch with an average biological yield of $349 \pm$ $336\left(\mathrm{mg} . \mathrm{m}^{3}\right)$ annually accounted for about $5 \%$ of the total planktonic biomass (Figure 3 and Table 3 ).

\begin{tabular}{|c|c|c|c|}
\hline Seasons & Factors & Dinoflagella & $\begin{array}{l}\text { Total Phyto- } \\
\text { plankton }\end{array}$ \\
\hline \multirow[t]{2}{*}{ Spring } & $\begin{array}{l}\text { Density (n. } \\
\left.\mathrm{m}^{-3} \times 10^{6}\right)\end{array}$ & $88.2 \pm 36.4$ & $135.8 \pm 69.9$ \\
\hline & $\begin{array}{l}\text { Bio- } \\
\text { mass }\left(\mathrm{mg}^{-3} \mathrm{~m}^{-3}\right)\end{array}$ & $1075 \pm 473$ & $21727.9 \pm 57710.4$ \\
\hline \multirow[t]{2}{*}{ Summer } & $\begin{array}{l}\text { Density (n. } \\
\left.\mathrm{m}^{-3} \times 10^{6}\right)\end{array}$ & $4.7 \pm 2.5$ & $244.9 \pm 196.2$ \\
\hline & $\begin{array}{l}\text { Bio- } \\
\text { mass }\left(\mathrm{mg}^{-3} \mathrm{~m}^{-3}\right)\end{array}$ & $351 \pm 13$ & $892.3 \pm 131$ \\
\hline \multirow[t]{2}{*}{ Autumn } & $\begin{array}{l}\text { Density (n. } \\
\left.\mathrm{m}^{-3} \times 10^{6}\right)\end{array}$ & $5.4 \pm 1.6$ & $352.31 \pm 187.4$ \\
\hline & $\begin{array}{l}\text { Bio- } \\
\text { mass }\left(\mathrm{mg} \cdot \mathrm{m}^{-3}\right)\end{array}$ & $130 \pm 50$ & $451.43 \pm 357$ \\
\hline \multirow[t]{2}{*}{ Winter } & $\begin{array}{l}\text { Density }(\mathrm{n} \\
\left.\mathrm{m}^{-3} \times 10^{6}\right)\end{array}$ & $12.5 \pm 13.9$ & $915.5 \pm 83529.8$ \\
\hline & $\begin{array}{l}\text { Bio- } \\
\text { mass }\left(\mathrm{mg}^{-3} \mathrm{~m}^{-3}\right)\end{array}$ & $129.7 \pm 50$ & $3417.3 \pm 1317.4$ \\
\hline
\end{tabular}

Table 4: Density (number per cubic meter $\times 106$ ) and biomass (milligrams per cubic meter) of Dinoflagella phylum in different seasons.

In the seasonal study of Dinoflagella phylum, the highest density was observed $(88.2 \pm 36.4)$ per cubic centimeter $\times 10^{6}$ and the highest biomass was $473 \pm 1075$ mg cubic meters in spring.

While the highest density and biomass of phytoplankton in the winter was $83529.8 \pm 5.915 \mathrm{~m}^{3} \times 10^{6} \mathrm{~m}^{3}$ and $1317.4 \pm 3 \mathrm{~m}^{3}$ respectively.

However, the lowest density of this phylum was observed in the summer $\left(4.7 \pm 2.5 \mathrm{~m}^{-3} \times 10^{6}\right)$ and the lowest biomass was in the winter $\left(129,7 \pm 50 \mathrm{mg} \cdot \mathrm{m}^{-3}\right)$ (table 4$)$.

\section{Discussion}

In this study, 24 species of Dinoflagella were identified and so Dinoflagella are heat-loving, but the highest number of species was in winter and late spring. With increasing temperature, density of Dinoflagella increased, which can be due to nutrients entering of river in the spring and in the winter because of low flood water due to rainfall, he said [13] And in Bering Sea, with the area of the Pacific coast of Kamchatka, ranks second in terms of dinophyte fioral abundance: 123 species which is 2.5 times as less as the Japan Sea, i.e., 35 genera, 21 families. The reduction in species numbers is due to a significant decline. In warm-water representatives of large genera $[14,15,16,17,18]$.

Because of the Caspian Sea ecosystem and having a variety of biological conditions to grow Dinoflagella, the characteristics of production in different regions of the Caspian Sea are quite different Seasonal variations in different ways such as effect on water temperature, river entrances and consequently increased nutrients, water currents and salinity changes at river entrances 
can have important impacts on Dinoflagella population changes. Also, in the southern coast of the Caspian Sea, the distribution of Dinoflagella in the blue column (from surface to depth 100 meters) was different and With increasing depth, there was a significant decrease $(p<0.05)[19,20]$.The Shannon-Weaver index in open ecosystem varies from 1 to 3.5 according to the frequency of phytoplankton [7] and in this area, it varied from 1.84 to 2.48 . Shannon Index was different in seasons and different in areas of the southern Caspian Sea. Although in this study, the highest Shannon index $\left(\mathrm{H}^{\prime}\right)$ was in the spring, but the lowest number of species were observed this season due to increased phytoplankton cells.

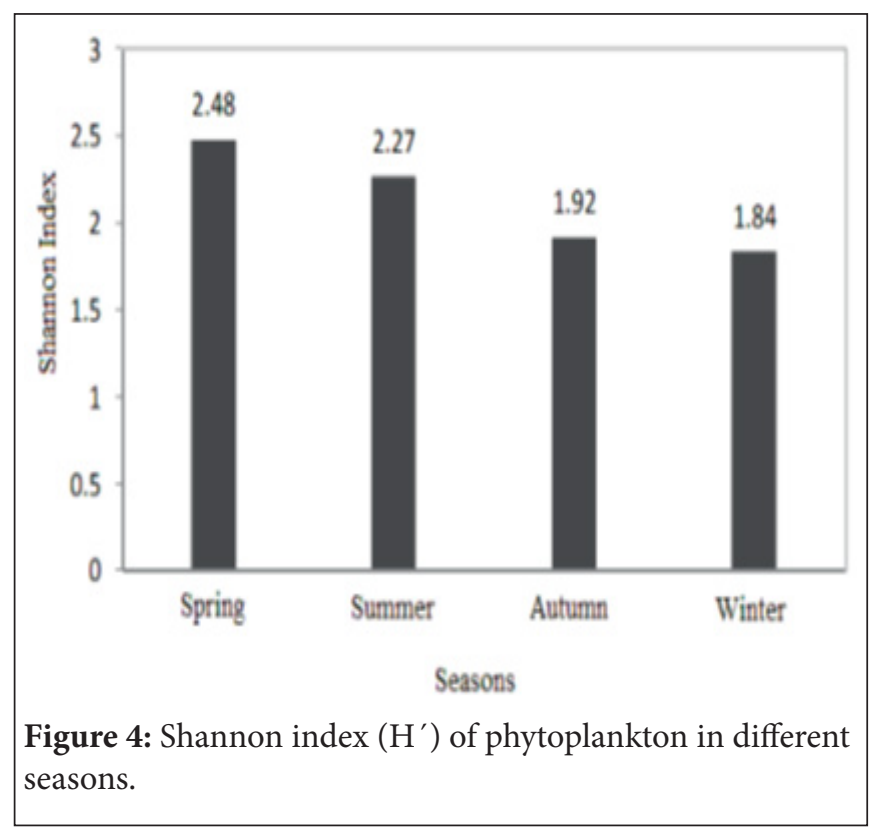

Dinoflagella population changes in the deep parts of the Caspian Sea, independent of weather conditions of the region and the presence of cold water in the deeper layers of the Caspian Sea, allows changing the population of Dinoflagella in deeper layers. The study also showed that there was a significant difference between the frequency of Dinoflagellate in the deep layers of the sampling $(\mathrm{p}<0.05)$. However, due to the rotation anti-cyclone in the Coastal zone of the southern Caspian Sea basin, no significant difference was observed in Dinoflagella species in the studied lines $(p>0.05)[21,22,23]$.

According to Dodge 1975, 1989, Balech 1977, 1985; Dodge and Saunders 1985 [15,16,17] studies, changes in dinoflagellate systematic which have occurred during recent decades, especially with regard to such large genera as Prorocentrum and Gonyaulacaceae. Overall, in this study Dinoflagella diversity have change significantly with the change of seasons and therefore an important factor in the development of Dinoflagella season is in the southern Caspian Sea As well as diversity in recent years and the density of Dinoflagella of this area have been significant changes that can harm the overall health of the Caspian Sea [23]. In the late eighth century in the Trans-Pacific scientists began a series of studies that examine of diatoms, Dinoflagella and Coc-

\section{colith were ended.}

Any significant increase in the population of plankton and fish migration pattern may be impacted on their growth rate, mortality rate, and of course the critical gas concentrations in the atmosphere and obviously, this set of changes can have a significant impact on the fate of Human.

\section{References}

1. Plotnikov I, Aladin N, Cretaux JF, Micklin Ph, Chuikov Yu et al. (2006) Biodiversity and recent exotic invasions of the Caspian Sea. Limnoogyl 29: 2259-2262.

2. Wetzel RG (2001) 3 eds. Limnology. Academic Press, California. Pp. 109-117.

3. Špoljar M, Lajtner J, Dražina T, Malekzadeh VR, Radanović I, et al. (2017) Disentangling food webs interactions in the littoral of temperate shallow lakes. Natura Croatica 26: 145-166.

4. Laloei F, Roshantabari M, Roohi A, Ganjian Khanari A, Hashemian A et al. (1999) Hydrology and Hydrobiology of the Southern Caspian Sea with the regards of some environmental studies, Caspian Sea Research Institute of Ecology, Final Report.

5. Shiganova TA, Niermann U, Gugu A, Kideys A, Khoroshilov V (1998) Changes of species diversity and their abundance in the main components of pelagic community after Mnemiopsis leidyi invasion. "NATO Scientific Affairs Division" in: Ecosystem Modeling as a Management Tool for the Black Sea. Kluwer Academic Publishers. Pp. 171-188.

6. Roohi A (2009) Population dinamic and effects of the invasive species Ctenophore Mnemiopsis leidyi in the Southern Caspian Sea. University Sains, Malaysia Pp. 152.

7. Mason CF (1998) Biology of freshwater pollution. Longman Scientific and Technical Biology. $400 \mathrm{p}$.

8. Špoljar M, Dražina T, Lajtner J, Duić Sertić M, Radanović I et al. (2018) Zooplankton assemblage in four temperate shallow waterbodies in association with habitat heterogeneity and alternative states. Limnologica, 71: 51-61.

9. CEP. 2001. Caspian Environmental Program, Mnemiopsis workshop (Baku, 24-26 April 2001) final report; CEP Wb site: http://www Caspian environment. org/biodiversity/meeting. 307 p.

10. Shannon CE, Weaver W (1963) The Mathematical Theory of Communication. University of Illinois Press. Urbana, $117 \mathrm{p}$.

11. Vollenweider AR, (1974) A manual on methods for measuring primary production in aquatic enviromantal. Blackwell scientific Publication. Oxford, london. Pp. 423.

12. APHA S (2005) Standard Methods. American Public Health association. Washington, DC 2005, USA. 346.

13. Makaremi M, Sabkara G, Kaffash MT (2006). Identification and distribution of phytoplankton in different areas of Anzali wetland and coastal areas of the Caspian Sea. Iranian J Fisheries 15: 129-149.

14. Dodge J D (1989) Some revisions of the family Gonyaulacaceae (Dinophyceae) based on a scanning electron microscope study. Botanica Marina 32: 275-98.

15. Balech E (1985) The genus Alexandrium or Gonyaulax of the tamarensis group. In oxic dinoflagellates (ed. D. M. Anderson, A. W. 
White and D. G. Baden), 33-38. Proceeding of the Third International Conference on Toxic dinoflagellates, St. Andrews. New Brunwiek, Canada 1985. New York: Elsevier.

16. Dodge JD, Saunders RD (1985) A partial revision of the genus Oxytoxum (Dinophyceae) with the aid of scanning electron microscopy. Botanica Marina 28: 99-122.

17. Balech E (1977) Cduatro especies de Gonyaulax, sensu lato, consideraciones sobre el genero (dinoflagellata). Revista del Museo Argentino de Ciencias Naturales Bernardino Rivadavia. Hidrobiologia 5: $115-36$.

18. Dodge JD (1975) The Prorocentrales (Dinophyceae). II. Revision of the taxonomy within the genus Prorocentrum. Bot J Linn Soc 71: 103-25.

19. Tahami FS, Mazlan Bin AG., Negarestan H, Lotfi Bin WM (2009) Identify of phytoplanktons in Caspian Sea waters. Conference Aq- uaculture 2009, Kuala Lumpur, Malaysia, Pp. 218.

20. Golaghaei M, Tahami FS, Makhlough A, Gangian A, Keyhansany AR et al. (2015) Distribution of phytoplankton in the Southern Caspian Sea in 2010, the Caspian Sea Ecological Research Center Pp.130.

21. Tahami FS (2012) Changes in phytoplankton community structure during the Mnemiopsis leidyi invasion of the Southern Caspian Sea (IRAN). Thesis for the degree of Ph. D of Marine Science. University kebangsan, Malaysia, Pp.260.

22. Hosseini SA, Rowshntabary M, Soleymaniroudi A, Makhlough A, Takmilian K et al. (2011) Hydrology and Hydrobiology of southern Caspian Sea. Iranian Fisheries Research Institute. Pp.510.

23. Finenko G, Kideys A, Anensky B, Shiganova TA, Roohi A et al. (2006) Invasive Ctenophore Mnemmiopsis leidyi in the Caspian Sea: feeding, respiration. reproduction and predatory impact on the zooplankton community. Mar Ecol Prog Ser 314: 171-185. 


\section{倜 \\ NIC \\ OPEN ACCESS PUBLICATIONS}

submit your manuscripts at

www. norcaloa.com 